International Journal of Child, Youth and Family Studies (2012) 2 \& 3: 198-213

\title{
ART PRACTICE AS POSSIBLE WORLDS
}

\section{Vanessa Clark}

\begin{abstract}
This paper explores the possibilities of arts practice in early childhood education. Building on her master's thesis, the author presents both a doing - her experimentation with arts practice in two early childhood centres - and an argument: that art may present an opening onto possible worlds. The author builds these worlds in relation to her theoretical framework: an immanent relational materialist onto-epistemology. Viewed through this lens, art's possible worlds have the potential to traverse, mix, and disrupt binaries that maintain marginalized positions. Art practice from this intersection of rupture is both intensely creative and deeply political.
\end{abstract}

Keywords: art, early childhood education, body, Deleuze and Guattari

Vanessa Clark is an atelierista (studio educator) for two projects with the Unit for Early Years Research and Development at the University of Victoria, P.O. Box 1700, STN CSC, Victoria B.C., Canada, V8W 2Y2. Email: vanessa.vondruska@gmail.com 
International Journal of Child, Youth and Family Studies (2012) 2 \& 3: 198-213

Springgay (2008) paraphrases Deleuze and Guattari in arguing that the body, "neither harbours consciousness nor is it biologically pre-determined, rather it is understood through what it can do - its processes, performances, assemblages and the transformations of becoming” (p. 3).

To understand what the body can do, we can start in the middle with Deleuze and Guattari's idea of a Body without Organs (BwO). The BwO is not literally an empty body: It is a body without organization or categorization (Grosz, 1994). The BwO is not necessarily the human body (Coleman, 2008): It can refer to a plant, an idea, a paintbrush, a sound (Davies, 1999). It can refer to any body. This account of the body highlights material and discursive interconnectedness.

As an artist, I understand that the artist does not necessarily choose her materials. The materials and the artist are drawn to each other. In my art, I use paint because it excites me, it interests me. I have worked for many years with paint, and we keep coming back to each other, as do I with the paintbrush. When I was young, I never cared much for holding a pen, but I wanted to hold a paintbrush. This body - the paintbrush - and what it was able to do fascinated me.

This paper explores what art can do, and how art works (Cox, 2011). To explore art means to move with art, not to close art down or capture it. Art presents an opening onto possible worlds. Viewed in this way:

art is something ... dangerous: a portal, an "access point” to another world of molecular becoming (our world experienced differently). As Deleuze and Guattari say, this, ultimately, is what makes art abstract, the "summoning" and making visible of otherwise imperceptible forces. (O’Sullivan, 2006, p. 50)

The systemic structures that govern early childhood education and care (ECEC) the Child Care Licensing Regulation, policies and procedures provided by the institution, developmental psychology’s “grand narrative”, and other typical narratives such as behaviourist social learning theories, Piagetian constructivism, and Vygotskian social constructivism (MacNaughton, 2003) - present tensions for the writing of this paper. By exploring possible worlds through a specific theoretical framework, I attempt to traverse these systemic structures. At the same time, I acknowledge that I practice early childhood education in the midst of these tensions, and that this location creates limitations, both for my work and for this paper.

Building on my master's thesis (entitled Disrupting The All-Too-Human Body Through Art In Early Childhood Education And Care), in this paper I present not only an argument but a doing: my experimentation with arts practice in two early childhood centres in which I set up an ethical-ecological environment for the children and their educators. My purpose is to demonstrate that art may present an opening onto possible worlds, worlds that might traverse, mix, and disrupt binaries that maintain marginalized 
International Journal of Child, Youth and Family Studies (2012) 2 \& 3: 198-213

positions. Art practice from this intersection of rupture is both intensely creative and deeply political.

The paper's first section, "Embodied Conversations with Materials”, discusses the lens I use: how this research is conceptualized and practiced. In “Abstract Movements”, I present my theoretical framework. A short description of my method is provided in the section titled "The Architect", which is followed by an analysis of "Possible Worlds". Concluding thoughts are presented in the paper's final section, "New Possibilities for Arts Practice".

\section{Embodied Conversations with Materials}

Artists may collect materials for an art piece based on a particular felt connection. Sandra Meigs, an artist and a professor in the University of Victoria's Faculty of Fine Arts, described her process for a painting she created that was hanging in the Vancouver Art Gallery (Meigs, 2011). The process began when she saw a small picture of an old house in a book she was reading. She was captivated by the style of the house. This felt connection grew as she found herself tracking down a university-owned heritage home of the same era and architecture as the picture in the book. She asked the university if she could stay in the home for a few weeks and draw. These drawings then became documentations from which she created paintings.

Gonzalo Lebrija, an artist born in Mexico City and living in Guadalajara, gave a lecture on his work at the Vancouver Art Gallery. One art piece I was particularly interested in was a map of his travels in Madrid on a toaster bike. At various points, when the environment affected him, he would take a picture of what he noticed, along with a picture of the odometer on his bike to document where he noticed it. He said, "the earth became my canvas, and my bike became the paintbrush” (Lebrija, 2011). The map was hung as a series of framed images side by side on a white wall.

Artist and lesbian rights activist Laiwan echoed this influence of the nonhuman world. She explained that she collected a large number of bus tickets over a period of about 10 years. When she collected the tickets, she didn't know she would make them into an art piece; she just really liked them. When she revisited the tickets more than 20 years later, she had the idea to write poetry with them. She wanted to write with something outside of herself, so she used a dictionary to write the poems. Her artistic process was about moments, she explained; she wanted to "open up time and space" (Laiwan, 2010). She wanted the piece she created to be a body to engage with. Lenz Taguchi (2010) terms this relationship between human and nonhuman bodies "intraactivity":

Intra-activity here relates to physicist terminology and to relationships between any organism and matter (human and non-human). Hence, what Barad and other material feminists (Alaimo \& Hekman, 2008) are suggesting is that it is not only humans that have agency - the possibility of intervening and acting upon others and the world. Rather, all matter can be understood as having agency in a 
relationship in which they mutually will change and alter in their ongoing intraactions. (p. 4)

In this account, humans are not given ontological primacy over nonhuman bodies. In fact, this distinction breaks down as we look to assemblages and the entanglements between all bodies. I understand both human and nonhuman bodies in assemblages to be “actants”, although with "different types and degrees of power” (Bennett, 2010, p. 108). Haraway (1992) echoes this problem of power as an issue of semiotics:

Non-humans are not necessarily "actors" in the human sense, but they are part of the functional collective that makes up an actant. Action is not so much an ontological as a semiotic problem. This is perhaps as true for humans as nonhumans, a way of looking at things that may provide exits from the methodological individualism inherent in concentrating constantly on who the agents and actors are in the sense of liberal theories of agency. (p. 331)

The problem for me then becomes how to articulate this agency without speaking for the other. Here I connect to Deleuze and Guattari (1987), whose rejection of representation "extends to the theorist, who should . . . speak only on her or his own behalf, and form connections and relays, not represent others” (Robinson \& Tormey, 2010, p. 25). Taking the position that the nonhuman world has agency, I speak on my own behalf, as a situated body within my research, about how I am affected and how I affect the entanglement between both humans and nonhumans. My goal is to experiment with ways to connect these ideas with practice, more specifically, arts practice in ECEC.

Similar to Lenz Taguchi (2010) and her thinking with Barad (1998, 1999, 2007, 2008, as cited in Lenz Taguchi, 2010), the lens I employ in this paper is an ontoepistemology, that is, both ontology and epistemology. Theories of one will inevitably extend from the other. I understand ontology "in terms of planes, intensities, flows, becomings, linkages, rather than being, objects, qualities, pairs, and correlates” (Grosz, 1994, p. 162). This understanding requires taking, as do Grosz (1994), Lenz Taguchi (2010), and Skott-Myhre (2008), among others, a Deleuzian-inspired ontology of immanence. Bodies are constantly affecting and being affected by the bodies around them (Lenz Taguchi, 2010). The reason it is important to keep a notion of epistemology here is so that we do not fall into an illusion of boundless difference. The idea of epistemology is to know the difference between creative experimentation that breaks apart binaries and codes and merely re-enacting binaries and codes. As Haraway (1991) points out, "some differences are playful; some are poles of world historical systems of domination. 'Epistemology’ is about knowing the difference” (p. 12).

The lens I have sketched above is an immanent relational materialist ontoepistemology. This paper is situated within the reconceptualist literature in early childhood education, through feminist poststructural and posthumanist theory/practice. In the next section, “Abstract Movements”, I unfold selected concepts from Deleuze and Guattari (1987): the Body without Organs (BwO), assemblage, and haecceity. ${ }^{1}$ These

\footnotetext{
${ }^{1}$ Nietzsche termed these haecceities "becomings" (Cox, 2011), and this paper uses the latter term instead.
} 
International Journal of Child, Youth and Family Studies (2012) 2 \& 3: 198-213

concepts are unpacked not as an effort to get them right, but to see how they can move and flow, and what might make them explode (Cox, 2011).

\section{Abstract Movements}

Here the paper takes an abstract shift in my attempt to build possible worlds. By using the term "abstract", my intention is not to create a binary between abstract and concrete. Massumi (2002), paraphrasing Deleuze, writes, “The problem with the dominant models in cultural and literary theory is not that they are too abstract to grasp the concreteness of the real. The problem is that they are not abstract enough to grasp the real incorporeality of the concrete” (p. 5).

To explore the relationship between abstract and concrete, on March 26, 2011, I went to hear a panel discussion at the Vancouver Art Gallery in which Izabella Laba, a mathematician, Roy Miki, an artist/poet, and Sandra Meigs, an artist/painter, presented on the topic, Between Concrete and Abstract. I was intrigued by what Izabella Laba said mathematicians do, as it was similar to how I conceptualize what I am doing with the work of Deleuze and Guattari: "We use the abstract to do things such as build.... [In mathematics] we don't do anything that is not abstract” (Laba, 2011). Sandra Meigs echoed this view that the abstract and the concrete are the same: "There is no need to separate them. They are both experienced” (Meigs, 2011). Roy Miki recounted his late friend bpNichol's answer to the question, "What is it like to paint?”; Nichol, whose work Pages from Hell was then showing at the gallery, described painting as

like standing in an imaginary house, and seeing an imaginary staircase, walking over to the imaginary staircase and walking up to an imaginary door, opening the imaginary door and seeing an imaginary window, walking up to the imaginary window, and looking out to the real world. (Miki, 2011)

Sandra Meigs (2011) says she "truly believes that art is a realm that exists". In a sense, then, with this paper I am building realms, through art, using the work of Deleuze and Guattari (1987).

\section{The Body without Organs (BwO)}

The Body without Organs (BwO), as Deleuze and Guattari (1987) explain, “is what remains when you take everything away. What you take away is precisely the phantasy, and significances and subjectifications as a whole” (p. 151). What remains is desire, but in this sense, desire is not a lack (Springgay, 2008). Desire differs from Foucault's conception of power. Desire is a productive force (Skott-Myhre, 2008) and a magnetic attraction between bodies.

A BwO is something that is constructed, in two phases: "One phase is for the fabrication of the $\mathrm{BwO}$, the other to make something circulate on it or pass across it; the 
International Journal of Child, Youth and Family Studies (2012) 2 \& 3: 198-213

same procedures are nevertheless used in both phases, but they must be done over, done twice” (Deleuze \& Guattari, 1987, p. 152).

\section{Phase One: Experimentation.}

A BwO is made through experimenting with different assemblages of bodies: ideas, chairs, sounds, my body, your body, and so on. Each piece that connects within or on a $\mathrm{BwO}$ has different movements, potentials, and affects. Experimentation unlocks the potentials of the pieces in/on the BwO. Something new is created through this process. BwOs are continually made from connections of human and nonhuman bodies, matter, and discourses that then break down (Lenz-Taguchi, 2010; see also Massumi, 2002).

Deleuze and Guattari (1987) warn that some BwOs block the flow for connecting new assemblages and becomings. They differentiate between a full $\mathrm{BwO}$, an empty $\mathrm{BwO}$, and a cancerous BwO. The full BwO is able to break apart, form new relations, and continually enter into different assemblages (Buchanan, 1997). The empty BwO is built on the destruction of the structure from which it is made. I would argue that an example of an empty BwO would be the often-stereotyped "madness" of artists. The cancerous $\mathrm{BwO}$ is one that proliferates and becomes a "majoritarian assemblage",2 neo-liberal practices of art making, which have a pre-established goal for the children to do with the materials, enforced on the child by an educator (Clark, in press), may be an example. The hope is to create a full $\mathrm{BwO}$ where the movements, speeds, and reverberations are productive and allow for the formation of new connections, assemblages, and full BwOs (Buchanan, 1997).

Art, the event of art, is not about an essential thinking subject who acts on materials through her body. When an artist meets with paint, she feels the paint, embodies the paint, and becomes with the paint. It is a process with few organizing thoughts; it is more about finding pieces with which to connect and experiment. This process may not hold true for all arts practice, as many artists may view their process differently. The creativity of commercial artists is assembled through the gain of capital, which may be an example of a cancerous BwO (J. Smith, personal communication, September 5, 2011). In using the term experimentation, I do not intend to suggest a process devoid of thinking. To make a BwO, we need to take apart the self. The traditional idea of the self, carried forward from Descartes, is the idea of an essential thinking subject. In this view, the "I" is the organizer who represents the world through thought (Olsson, 2009; Williams, 1978).

Where psychoanalysis says "stop, find your self again,” we should say instead, "let’s go further still, we haven’t found your BwO yet, we haven’t sufficiently dismantled our self." Substitute forgetting for anamnesis, experimentation for interpretation. Find your body without organs. Find out how to make it. (Deleuze \& Guattari, 1987, p. 151)

\footnotetext{
${ }^{2}$ A majoritarian assemblage, according to Grosz (1994), is one that maintains binary aggregates of sexes, classes, and ages that result in fixed identities.
} 
International Journal of Child, Youth and Family Studies (2012) 2 \& 3: 198-213

In this view, the thinking self is an effect of life (Olsson, 2009). Thinking and self emerge through encounters between bodies. In this sense, when the body meets with paint, thinking and self emerge with paint. This view contrasts with humanist notions of self where the subject thinks about the paint as an object and the body acts as a means for the thinking subject to represent (Clark, in press). Each time the artist meets with paint, they meet one another in a new way. The artist can never know in advance what will become a part of the assemblage. Mood, ideas, emotions, the room, lights, sounds, smells, people, and other materials all may connect within the artistic process. Each body holds the potential to affect and be affected by the other bodies in different ways. Bennett (2010) explains that Deleuze invented the notion of "absorption" to describe "this kind of part-whole relationship: absorption is a gathering of elements in a way that both forms a coalition and yet preserves something of the agential impetus of each element” (p. 35).

Assemblage.

An alternative view of how parts relate to one another is conveyed by the idea of an assemblage. Bennett (2010) explains:

Assemblages are ad hoc groupings of elements, of vibrant materials of all sorts. Assemblages are living, throbbing confederations that are able to function despite the persistence of energies that confound them from within. They have uneven topographies, because some of the points at which the various affects and bodies cross paths are more heavily trafficked than others, and so power is not distributed equally across its surface. (pp. 23-24)

What the body of a child can do is understood by what assemblages it partakes in (Grosz, 1994). The body is "not the sum of the parts of its assemblages but rather an effect of the assemblage that is not separated from the world" (Olsson, 2009, p. 45). The body does not hold rigid boundaries, nor does it cease to exist. The body is both virtual and actual: material-incorporeal. It is the moment of (en)folding in time and space (Massumi, 2002). The assemblages, through the event, (en)fold the child's body.

\section{Phase Two: Becoming.}

An assemblage is a composition of bodies that mingle, resonate, and reverberate with one another (Bennett, 2010). The assemblage is relational and opens us to the inbetween. The space in-between is where things fray and undo. Springgay and Freedman (2009), paraphrasing Grosz (2001), write: “Contrary to dichotomous relations, in the middle something passes between two terms such that they are both modified putting them to strange new uses” (p. 30). In this way space is heterogeneous and continually multiplying (Springgay \& Freedman, 2009; see also Massumi, 2002). Experimentation and the connections between bodies actualize the virtual. The virtual is the realm of movement whose force is felt. Perceiving the virtual is a becoming (Manning, 2008). The idea of becoming requires that we focus on how something "becomes through its relations” (Coleman, 2008, p. 186). Becomings are relations to the felt force of the virtual. Experience is one instance of the world, whereas symbolic life is another. Becomings are moments of symbolic creation from experience. Arts practice works in this sense as a process of continual movement, force, becoming (Cox, 2011). 
The notion of becoming relates to the ideas of minoritarian and majoritarian assemblages (Grosz, 1994). A molar unity is a binary aggregate of sexes, classes, and races, for example. The binary contains both the privileged majoritarian assemblage that gains its meaning from the stability of the binary being acted out and the suppressed molecular assemblage that acts to destabilize the privileged identities. Binaries maintain minority positions, whose lines continually act to suppress (Grosz, 1994). Becomings are escapes from molar unities and "are always molecular, traversing and realigning" them (Grosz, 1994, p. 172). The extreme becoming is a complete de-stratification, a becomingimperceptible (Grosz, 1994). Becomings are perceived through experience, and thus are something to speak about and approach with humility and tension (Olsson, 2009). We can describe a becoming by the intensity of its collisions, movements, and reverberations. Becomings can also be referred to in terms of their semiotic creations, such as becomingwoman or becoming-child (Buchanan, 1997).

Having sketched my theoretical framework, I shift now to the classroom and describe the ethical-ecological environments I created for the children and the educators in those places.

\section{The Architect}

To create a full $\mathrm{BwO}$ is to open possibilities for new relations, connections, and assemblages (Buchanan, 1997). One way to create a full $\mathrm{BwO}$ is through arts exploration. When an artist engages in a creative process, she encounters the materials and the environment. Through each "encounter and negotiation", the potentials of the materials and the environment make themselves intelligible to her through forces and reverberations (Kind, 2010, p. 125). Artist Sylvia Kind (2010) contends that each material "holds" different forces, reverberations, and potentials. Inspired by her work, I set up an ethical-ecological environment for the children and educators in two different child care centres. I brought in standing Plexiglas, brushes, paint, shirts, and a drop cloth. I set up the materials in the classrooms in a way that allowed room for movement, and then invited all to the ethical-ecological environment.

The place of art striates experimentation (Lenz Taguchi, 2010). In this way the Plexiglas, paint, paintbrushes, drop cloth, and shirts I brought to each centre, along with the floor, furniture, temperature, light, and any ideas that might connect, suggest both ways of intra-acting and potentials for experimentation. A paintbrush, for example, suggests a way that the hand might hold the brush to best distribute paint on the Plexiglas. However, one might also hold two paintbrushes in one hand, no longer optimizing the brush in its intended use, but opening up possibilities for becoming. As educators, we can think with the materials as we create ethical-ecological environments with the children. To think with the materials, we may consider the materials striations as well as potentials for experimentation. To experiment and invent an environment for the classroom requires acknowledging that the direction and revelations of the composition of bodies might be dangerous. Bell (2007) argues: 
International Journal of Child, Youth and Family Studies (2012) 2 \& 3: 198-213

Ethics comes consonant with politics (as Latour also argues) because each can only be the practice of developing ethical-ecological environments, arrangements and compositions. To invent these is not to be able to direct the entities sustained there, which only by their appearance suggest - and only suggest - the "success" of any retrospectively imagined path of actualization. The impulse to offer optimism might lead one, with Grosz, to emphasize the productive role that any entity or composite has or holds as potential (and which only in that particular sense belongs to it), given the environment to sustain its emergence, given the right "inventions". But such optimism is to be tempered with all the hesitation that arise from acknowledgment that the reverberations of inventions may elaborate themselves in compositions and directions unintended and unwelcome. (pp. 119120, emphasis in original)

To embark on arts practice in this way takes both presence of body and the ability to critically engage with practice as it (en)folds. We can never predict what possibilities might emerge. In the classroom art explorations described in the section that follows, my body was part of the exploration, and my role in the process emerged through each encounter. I found myself experimenting with the children and introducing materials and directions to support the process. In "Possible Worlds" I link these ideas to practice by building on the abstract movements I discussed in this section (Robinson \& Tormey, 2010).

\section{Becoming-Paper-Blood-Hands}

\section{Possible Worlds}

In the classroom Justin encounters the red paint and Plexiglas as the red paint and Plexiglas encounter him. I watch as the Plexiglas and Justin stand so close to one another that the red paint almost connects with Justin's face. My body-camera stands frozen in anticipation. Then the red paint and his finger connect. Soon after, his hands connect with the Plexiglas, the paint speaking back and marking his hands.

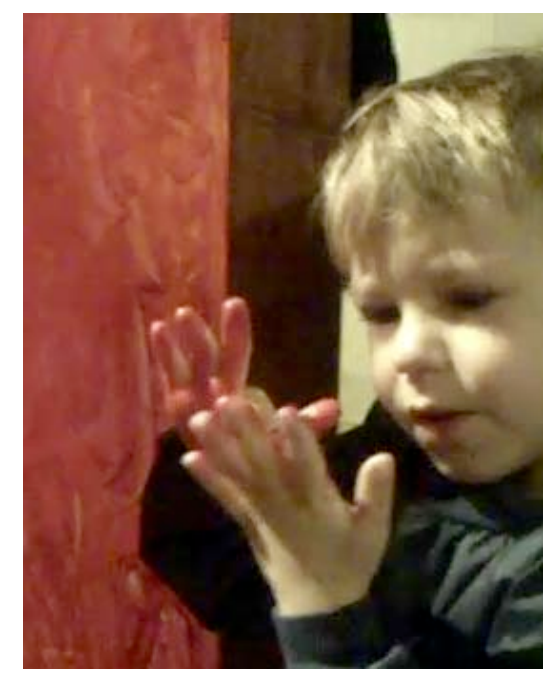


The paint explores Justin's hands as Justin's hands explore the paint. Justin encounters not only the paint, but his hands as well. Here we might say that the objects of knowledge are actants (Bennett, 2010; Haraway, 1992). We might introduce the actants as the entanglements and the relation between red paint, hands, and Justin. The actants engage in experimentation, among many more bodies within the assemblage. Through the assemblage, the forces collide, whereby transformations take place. The $\mathrm{BwO}$, prior to articulation, is desire. Desire, for Deleuze, "is not an attribute of a desiring subject but is a matter of flows and becomings which traverse the entire social, and indeed material or ecological field. Hence, desire is not something 'processed' by the sovereign subject but something inter-, sub- and extra-subjective” (Robinson \& Tormey, 2010, p. 22).

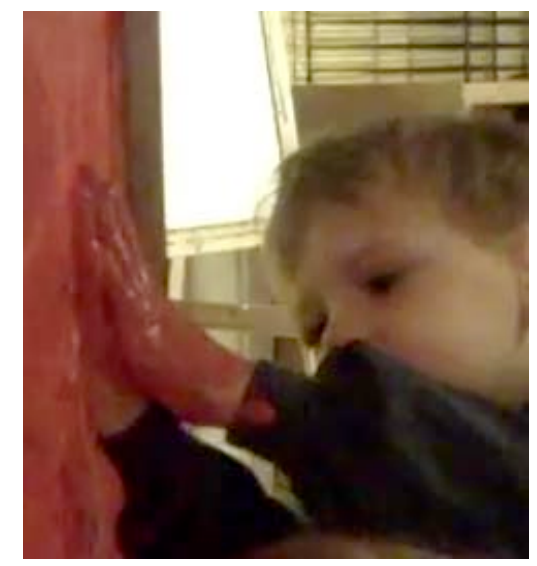

All of a sudden, I hear Justin say the following words:

Ah, bloody hands now (.6) They're paper-bloody-hands (.3) You can call me paper blood hands (.2) 'Cuz I got blood all over my hands (.1) Call me paper blood hands

Justin articulates the BwO. The flows, intensities, and non-stratified matters become "call me paper blood hands". This might be what Cox (2011) describes as a moment of symbolic creation from experience. A becoming, perhaps, emerges in relation to the experience and breakdown of the red-paint-hands-Justin assemblage. If we attend to the becoming, we might be able to see how the nomadic subject emerges: "call me paper blood hands”. Deleuze and Guattari put forward this notion of nomadic thinking, a thinking "that has no sedentary and stable place within which to perform its activity. This thinking not only deconstructs codes and habits but actually connects them together in new and unexpected ways” (Olsson, 2009, p. 25). Robinson and Tormey (2010) argue that, "the subject, where it exists, is a product of certain forms of desire, but only one of the possible outcomes of what is termed 'desiring-production'” (p. 22). This movement of a minoritarian assemblage also forces thought, we might suggest. As Hultman and Lenz Taguchi (2010) explain, "nomadic thinking produces another kind of knowing: knowing of what emerges in-between” (p. 538). Here we might be able to see desire as expressed through new ways of thinking (Olsson, 2009): the assemblages of becoming- 
paper-bloody-hands offering up another world, disfiguring the majoritarian assemblages through which we habitually come to see the world, traversing, mixing, and disrupting such binaries as human/nonhuman, man/tool, self/other.

\section{Phase One: Experimentation}

Ariel-paintbrush-dropcloth-cement floor-Plexiglas-paint-camera-lighttemperature-sounds-emotions-Vanessa: a bundle of relations come together and connect. Drawn to each other through experimentation. Exploring what art and bodies can do. My camera-body moves with Ariel-paintbrush-Plexiglas-paint. Pink dots form as bodies connect, making visible imperceptible forces through the event.

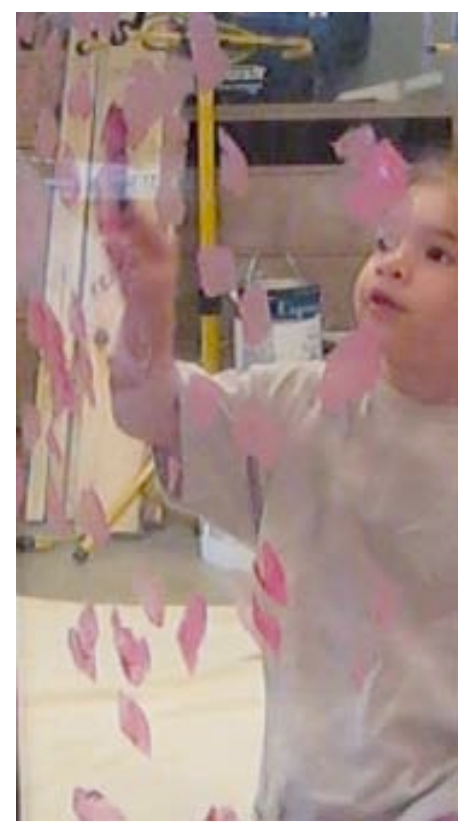

The assemblage of bodies, a desiring-production, makes its own connections through experimentation. The bodies become different as an effect of their constellations, not a categorical difference to one another; each body becomes different-in-itself. Bignall (2007, p. 202, as cited in Pacini-Ketchabaw \& Nxumalo, 2010) describes this difference as "internal to a body as it transforms over time" (p. 146). This difference emerges not through imitating other bodies. It is a matter of a body joining into a composition with other bodies:

Difference is thus caused by connections and relations within and between different bodies, affecting each other and being affected, whether it is viruses, humans or sand. This makes each of these bodies differentiate in themselves, continuously - one singular event after the other. (Hultman \& Lenz Taguchi, 2010, p. 529) 
We might ask how each body is becoming different-within-itself as an effect of its relations within the composition of other bodies (Clark, 2012, drawing from PaciniKetchabaw \& Nxumalo, 2010).

\section{Phase Two: Becoming}

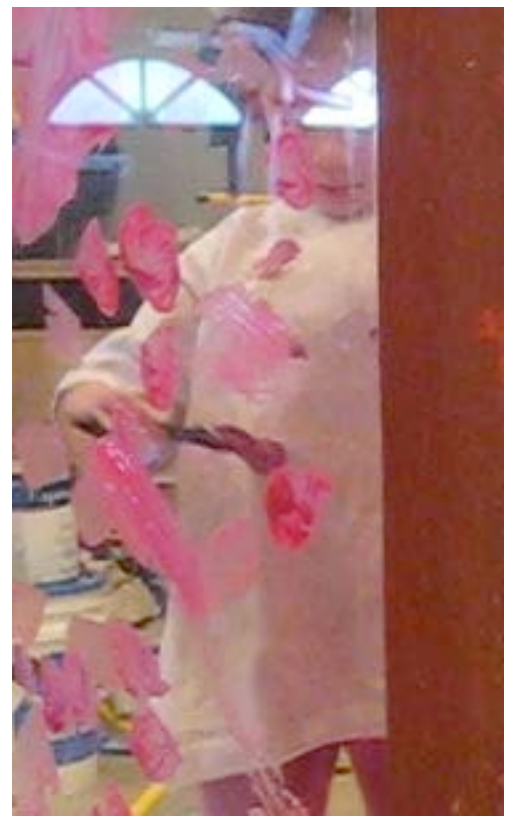

The relation between Ariel's body, paintbrush, and paint produces her body as a surface on which the paint can spread and move. Ariel's body (en)folds as a becomingcanvas (S. Kind, personal communication, June 23, 2010). In this way, the paintbrush has a voice through its relation within the assemblage. Painting "visualize[s] invisible forces" whereby the paint is becoming-sensation (Grosz, 2008, p. 81). This is not to suggest that these are the only becomings provoked by these images. To become-with these images through an immanent relational materialist onto-epistemology is to continually (en)fold (Lenz Taguchi, 2011). Each time my body encounters these images, it encounters them in a different way; thus these images present multiplying becomings. Expanding the network of connections, we can look at the assemblage of these bodies all together and through the event as becoming-art. At the same moment, the immanent relation between these bodies can transform once again. We can look at the connections between the images and text and my body sitting on a chair, the laptop under my hands, black keys beneath my fingers, the tapping sounds each time my fingers press down on keys, the articles and books piled around my body on the floor, on my desk, and on shelves in front of me, the ideas emerging from among these connections as the space multiplies onwards - all of this, and more - as becoming-research. As O’Sullivan (2006) expresses it, “our world consists of moments of becoming, the mingling of bodies, the meeting of forces, a constant interpenetration and interconnection of all phenomena. There is no beginning or end to this process” (p. 56). 
International Journal of Child, Youth and Family Studies (2012) 2 \& 3: 198-213

\section{New Possibilities for Arts Practice}

It is an illusion to think that we can work and live only within the creative intensities that arts practice elaborates. With this paper, I am not suggesting that we focus on art merely as a space for creativity, as doing so may blind us to the coded binaries (Haraway, 1991) that operate in the classroom. The institution of early childhood and the various theoretical perspectives that govern it machinate possibilities for existing in this coded space. For example, the majoritarian assemblages of developmental psychology produce and maintain formed and fixed binary aggregates of sexes, classes, and ages in the classroom. These fixed individualist identities then create boundaries that separate educator from child, self from other, child from environment, child from child ${ }^{3}$. Further, the institution of early childhood disseminates policies and procedures wherein the identities of the educator and child are delineated and their bodies regulated in the classroom (MacNaughton, 2003). Arts practice continues to be inscribed by these transcendent modes of reality that suppress ways of being in the world.

Yet the possibilities of arts practice are boundless, and this paper has glimpsed only a few. Arts practice through the Deleuzian concepts of $\mathrm{BwO}$, assemblage, and becoming presents an opportunity for political and ethical action in the classroom - an action to traverse, mix, and disrupt the powerful structures that claim our classrooms, and to open up “lines of flight” (Deleuze \& Guattari, 1987).

This paper presents a new problem for early childhood practice, and in particular for arts exploration in early childhood: how to make a BwO, a full BwO that can break apart, form new relations, and continually enter into different assemblages (Buchanan, 1997). As we turn our focus to what bodies are doing - how they experiment, assemble, and become - we open to the immanent entanglement of bodies through the $\mathrm{BwO}$, and this allows us to perceive the felt forces of continual transformation and becoming.

We cannot know in advance what a body can do or what a body is capable of becoming (Springgay, 2008; Skott-Myhre, 2008). Bodies assemble and disassemble as they are machined through desire. Lines of flight might be produced through the emergent becomings this paper has explored. Minoritarian assemblages of becomingpaper-blood-hands, becoming-canvas, becoming-art, and becoming-research hold potential to traverse and rupture majoritarian assemblages of human/nonhuman, self/other, researcher/data, educator/child, and artist/materials. Here the rigid binaries chaining the body may be sloughed off. The body opens to the flow and movement of the virtual.

\footnotetext{
${ }^{3}$ Within humanist practices of individuality, children are encouraged to "celebrate diversity" and to tolerate each other in spite of their differences (Pacini-Ketchabaw \& Nxumalo, 2010).
} 
International Journal of Child, Youth and Family Studies (2012) 2 \& 3: 198-213

\section{References}

Bell, V. (2007). Culture and performance: The challenge of ethics, politics, and feminist theory. New York: Berg.

Bennett, J. (2010). Vibrant matter: A political ecology of things. Durham, NC: Duke University Press.

Bignall, S. (2007). Indigenous peoples and a Deleuzian theory of practice. In A. HickeyMoody \& P. Malins (Eds.), Deleuzian encounters: Studies in contemporary social issues (pp. 197-211). Basingstoke, UK: Palgrave Macmillan.

Buchanan, I. (1997). The problem of the body in Deleuze and Guattari, or, what can a body do? Body and Society, 3(3), 73-91.

Clark, V. (in press). Art making as a political and ethical practice. Canadian Children, 36(2).

Clark, V. (2012). Becoming nomadic through experimental art making with children. Manuscript submitted for publication.

Coleman, R. (2008). The becoming of bodies. Feminist Media Studies, 8(2), 163-179.

Cox, C. (2011). Beyond representation and signification: Toward a sonic materialism. Journal of Visual Culture 10(2), 145-157. DOI: 10.1177/1470412911402880

Davies, B. (1999). A body of writing 1990-1999. New York: Altamira Press.

Deleuze, G., \& Guattari, F. (1987). A thousand plateaus: Capitalism and schizophrenia. Minneapolis: University of Minnesota Press.

Grosz, E. (1994). Virtual bodies. Bloomington, IN: Indiana University Press.

Grosz, E. (2008). Chaos, territory, art. New York: Columbia University Press.

Haraway, D. (1991). Simians, cyborgs and women: The reinvention of nature. New York: Routledge.

Haraway, D. (1992). The promises of monsters: A regenerative politics for inappropriate/d others. In L. Grossberg, C. Nelson, \& P. A. Treichler (Eds.), Cultural studies (pp. 295-337). New York: Routledge.

Hultman, K., \& Lenz Taguchi, H. (2010). Challenging anthropocentric analysis of visual data: A relational materialist methodological approach to educational research. International Journal of Qualitative Studies in Education, 23(5), 525-542. doi:10.1080/09518398.2010.500628 
International Journal of Child, Youth and Family Studies (2012) 2 \& 3: 198-213

Kind, S. (2010). Art encounters: Movements in the visual arts and early childhood education. In V. Pacini-Ketchabaw (Ed.), Flows, rhythms, and intensities of early childhood education curriculum (pp. 113-131). New York: Peter Lang.

Laba, I. (2011). Between abstract and concrete [Lecture notes]. Vancouver, BC: Vancouver Art Gallery.

Laiwan. (2010). Artist talk [Lecture notes]. Vancouver, BC: Vancouver Art Gallery.

Lebrija, G. (2011). The distance between you and me [Lecture notes]. Vancouver, BC: Vancouver Art Gallery.

Lenz Taguchi, H. (2010). Going beyond the theory/practice divide in early childhood education. New York: Routledge.

Lenz Taguchi, H. (2011) Investigating learning, participation and becoming in early childhood practices with a relational materialist approach. Global Studies of Childhood, 1(1), 36-50. doi.org/10.2304/gsch.2011.1.1.36

MacNaughton, G. (2003). Shaping early childhood: Learners, curriculum, and contexts. London: Open University Press.

Manning, E. (2008). Colouring the virtual. Configurations, 16(3), 325-346. doi: 10.1353/con.0.006

Massumi, B. (2002). Parables for the virtual. Durham, NC: Duke University Press.

Meigs, S. (2011). Between abstract and concrete [Lecture notes]. Vancouver, BC: Vancouver Art Gallery.

Miki, R. (2011). Between abstract and concrete [Lecture notes]. Vancouver, BC: Vancouver Art Gallery.

Olsson, L. (2009). Movement and experimentation in young children's learning: Deleuze and Guattari in early childhood education. New York: Routledge.

O’Sullivan, S. (2006). Art encounters: Thought beyond representation. New York: Palgrave Macmillan.

Pacini-Ketchabaw, V., \& Nxumalo, F. (2010). A curriculum for social change: Experimenting with politics of action or imperceptibility. In V. Pacini-Ketchabaw (Ed.), Flows, rhythms, and intensities of early childhood education curriculum (pp. 133-154). New York: Peter Lang. 
International Journal of Child, Youth and Family Studies (2012) 2 \& 3: 198-213

Robinson, A., \& Tormey, S. (2010). Living in smooth space: Deleuze, postcolonialism and the subaltern. In S. Bignall \& P. Patton (Eds.), Deleuze and the postcolonial (pp. 20-40). Edinburgh: Edinburgh University Press.

Skott-Myhre, H. (2008). Youth and subculture as creative force: Creating new spaces for radical youth work. Toronto: University of Toronto Press.

Springgay, S. (2008). An ethics of embodiment, civic engagement and a/r/tography: Ways of becoming nomadic in art, research and teaching. Educational Insights, 12(2), 1-11.

Springgay, S., \& Freedman, D. (2009). M/othering a bodied curriculum: Sleeping with cake and other touchable encounters. Journal of Curriculum Theorizing 25(2), 25-36.

Williams, B. (1978). Descartes: The project of pure enquiry. Sussex, UK: Harvester Press. 